Article

\title{
Towards Ecological-Economic Integrity in the Jing-Jin-Ji Regional Development in China
}

\author{
Suxiao Li ${ }^{1}$, Hong Yang ${ }^{2,3}$, Junguo Liu ${ }^{4}(1)$ and Guangchun Lei ${ }^{1, *}$ \\ 1 School of Nature Conservation, Beijing Forestry University, Qinghua East Road 35, Haidian District, \\ Beijing 100083, China; lisuxiao2014@126.com \\ 2 Eawag, Swiss Federal Institute of Aquatic Science and Technology, Uberlandstrasse 133, 8600 Dubendorf, \\ Switzerland; hong.yang@eawag.ch \\ 3 Department of Environmental Science, MGU, University of Basel, Vesalgasse 1, 4051 Basel, Switzerland \\ 4 Guangdong Provincial Key Laboratory of Soil and Groundwater Pollution Control, School of Environmental \\ Science and Engineering, Southern University of Science and Technology, Xueyuan Road 1088, Nanshan \\ District, Shenzhen 518055, China; junguo.liu@gmail.com or liujg@sustc.edu.cn \\ * Correspondence: guangchun.lei@foxmail.com; Tel.: +86-10-6233-6717
}

Received: 25 October 2018; Accepted: 12 November 2018; Published: 14 November 2018

\begin{abstract}
In China, the regional development policy has been shifting from solely economic orientation to ecologically sound economic growth. Using the Beijing-Tianjin-Hebei (Jing-Jin-Ji) region as a case study, we evaluated the temporal variations in ecosystem service values (ESVs) associated with land use changes from 1990 to 2015. We analyzed the dynamic relations between ESVs and the economy (indicated by the gross domestic product, GDP) by introducing the elasticity indicator (EI), which reflects the growth synchronism between the two, and the ecosystem service load (ESL), which reflects the ecological efficiency of economic growth. The results showed that the land use changes in Jing-Jin-Ji have been characterized by decreases in water areas, cropland, and grassland and increases in woodland and built-up areas. The ESVs of woodland and water areas contributed to $80 \%$ of the total ESV of the region, and the total ESV increased by $13.87 \%$ as a result of an area increase in woodland (26.87\%). The average EI of Jing-Jin-Ji improved from 0.028 to 0.293 over the study period, indicating that the growth of ESVs was being balanced with the growth in the GDP. The average ESL decreased by 1.24, suggesting a significant improvement in ecological efficiency per unit GDP. Within the Jing-Jin-Ji region, large disparities in EI and ESL were shown to exist among Beijing, Tianjin, and Hebei owing to their differences in ecological resources, GDP compositions, and development levels. The study highlights the needs to reinforce woodland and water conservation, adjust economic structures, and balance the intraregional development to achieve the ecological-economic integrity of the region.
\end{abstract}

Keywords: ecosystem service value; land use change; elasticity indicator; ecosystem service load; Jing-Jin-Ji

\section{Introduction}

Until very recently, human development has been coupled with a conflicting relationship between ecological wellness and socioeconomic prosperity. The ecosystem and its services have been ignored and overexploited in humanity's long pilgrimage to economic growth, which has resulted in a worldwide degradation of the ecosystem and the detriment of biodiversity [1]. Since the reform and opening policy, China's economy has grown the fastest among all major nations [2], with the intensification of ecological deterioration being led by the excessive withdrawal of water, relentless land reclamation, deforestation, and overgrazing [3]. The rising appreciation of the critical role of 
ecosystems in providing goods and services that contribute to human welfare has highlighted the importance of an ecological economics approach to sustainability $[4,5]$. The integration of ecology and economics has been increasingly endorsed in the policy arena worldwide [6-9].

The monetary valuation of ecosystem services provides an intuitive and comparable way to show the values that are inherent in complex ecosystem processes. At the global level, Costanza et al. [6] proposed the benefit transfer method, which assumes a constant unit value per hectare of ecosystem type and multiplies that value by the area of each type for an aggregated total. Using this method, they estimated the world ecosystem service value (ESV) to be US $\$ 45.9$ trillion/year (2007 dollars) for 17 types of ecosystem services of the 16 biomes $[6,10]$. The total ESV decreased to US $\$ 41.6$ trillion/year by 2011 owing to decreases in tropical forests, wetlands, and coral reefs, which have high unit values [10]. By reviewing more than 320 publications, De Groot et al. [11] estimated the value of ten main biomes to range from US $\$ 490$ /year for open oceans to US $\$ 350,000 /$ year for coral reefs. In China, using the market value method, Ouyang et al. [12] conducted a primary study on monetary valuation for forest, grassland, cropland, wetland, and desert areas of China. They estimated the total national ESV to be 34 trillion Yuan/year (approximately US $\$ 4.4$ trillion in 2007 dollars). Utilizing Costanza's method, Xie et al. modified the ecosystem classifications and unit values of ecosystem types based on two surveys of 700 Chinese ecologists [13]. Their estimation of the Chinese national ESV was 38.1 trillion Yuan/year (approximately US $\$ 4.96$ trillion in 2007 dollars) from 11 types of ecosystem services provided by 14 biomes in 2010 [14]. Many studies adopted the unit value calculated by Xie et al. [14] to evaluate the national or local ESVs in China [15-18]. Although the importance of ecosystem services was addressed through value estimations, further research is needed to explore the changing ecosystem services in a coupled human-natural system [19-21].

In recent years, in its socioeconomic development strategy, China has been experiencing a transition from pursuing purely economic growth to prioritizing ecological conservation. During this transition, the landscape patterns, ecological conditions, and economic performance have greatly varied. China's development over the past three decades can be divided into three phases: the economy supreme phase before 2000, which was characterized by ensuring gross domestic product (GDP) increase at the expense of natural resources; the ecological awakening phase from 2000 to 2012, during which China released policies and increased investments for ecosystem protection along with economic development; and the ecological civilization phase beginning in 2012, which featured the alignment of economic growth with ecological protection. Within the context of enhancing ecosystem conservation, many studies have examined the achievements of China's policies on ecosystem services from the national perspective [2,22]. Recent studies highlighted the tradeoffs between natural capital and economic development by incorporating ESV analysis into economic performance [23-25]. Nevertheless, few studies have explored the temporal trajectories of the interactions between ecosystem and economy, especially at the regional level. Addressing questions such as "How have regional ESVs and GDP changed over time, and what is the dynamic relationship between the two?" is necessary to pursue a more balanced and sustainable development path in a region.

The Beijing (Jing)-Tianjin (Jin)-Hebei (Ji) (Jing-Jin-Ji) region is the political and economic center of China. Extensive economic development in this region over the past decades has placed enormous pressure on the ecological environment [26]. With the implementation of ecologically friendly policies, such as the forest protection projects "grain for green", "the key shelter belt construction", and "Beijing-Tianjin sandstorm control" [3]; the establishment of a wetland conservation system [27]; and implementation of the "Jing-Jin-Ji coordinated development" strategy in 2014 [28], this region entered a new era of ecological conservation. In this paper, we use Jing-Jin-Ji as the study region to explore the dynamic relationship between ESVs and economic development to support decision-making to achieve balanced ecological-economic development. The overall aim of the study is to investigate whether ESVs and GDP have changed synchronously in the context of China's three development phases. The specific objectives of this study are as follows: (i) to reveal the changes in ESVs in response to land use changes; (ii) to analyze the dynamic relationship between ESVs and 
economic growth; and (iii) to identify the regional disparities in development among Beijing, Tianjin, and Hebei.

\section{Materials and Methods}

\subsection{Study Area}

The Jing-Jin-Ji region is in Northern China between $113^{\circ} 04^{\prime}-119^{\circ} 53^{\prime} \mathrm{E}$ and $36^{\circ} 01^{\prime}-42^{\circ} 37^{\prime}$ $\mathrm{N}$, covering an area of $216,000 \mathrm{~km}^{2}$, which accounts for $2.3 \%$ of the national territorial area of China (Figure 1). It contains China's capital city, Beijing, the Tianjin municipality, and 11 city-level administrative entities in Hebei province. It has a population of approximately 110 million, accounting for $7.23 \%$ of the national population, and had a GDP equivalent to $10 \%$ of China's total in 2015 . Jing-Jin-Ji is not only the national political and cultural center, but it is also the most developed economic core in Northern China. It is the third Chinese economic growth pole after the Yangtze Delta and Pearl River Delta. However, the rapid economic development came with a high ecological cost, causing degradation such as air and water pollution, water resource pressure, soil erosion, and loss of ecological and environmental carrying capacities, which have hindered sustainable economic development and future human wellbeing [29-32].

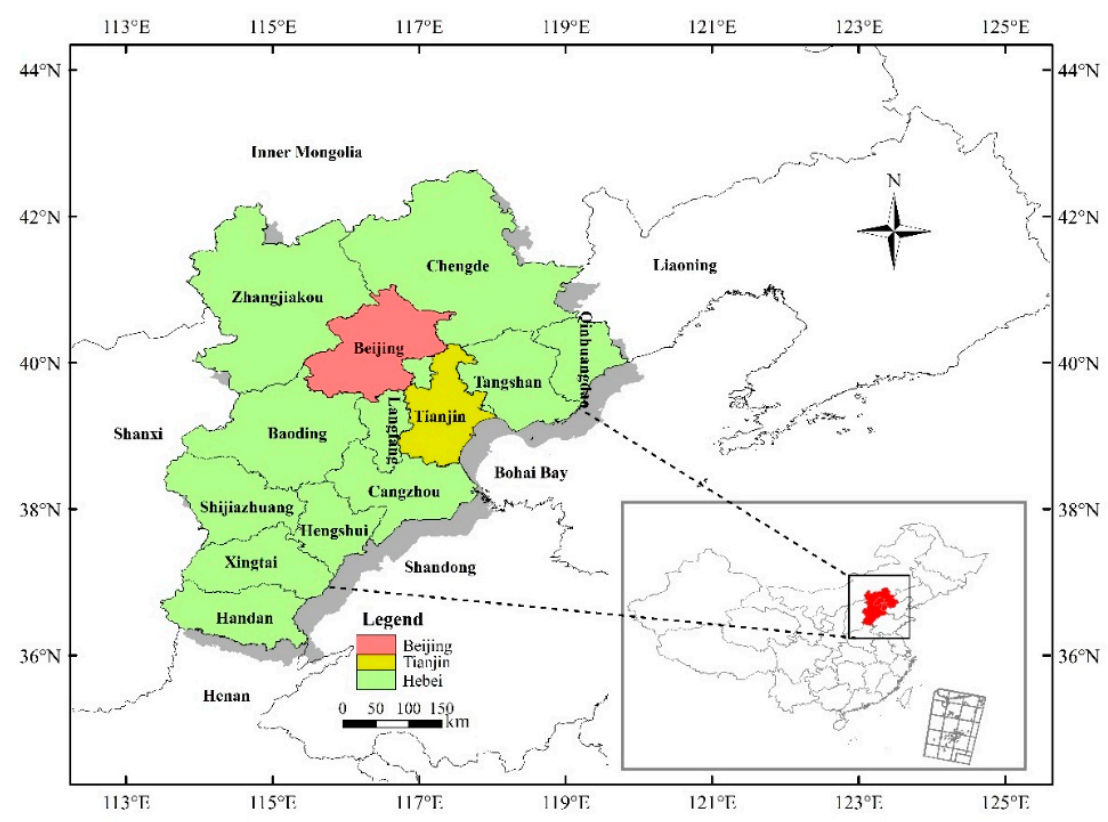

Figure 1. The location of the Jing-Jin-Ji region.

\subsection{Data Source and Processing}

Land use data from 1990, 2000, 2010, and 2015 were obtained from the Data Center for the Resources and Environmental Sciences, Chinese Academy of Sciences (RESDC). The land use types were interpreted from satellite imagery and had an overall accuracy of $94.3 \%$ [33]. For the purpose of ecosystem service valuation, we aggregated the ten original types of land use into six major types (Table A2, Appendix B), namely, cropland including dry cropland and paddy land; woodland including coniferous, broadleaf forest, and shrub; grassland including both dense and sparse grass; water areas including water bodies and wetlands; built-up areas; and bare land. Land areas that did not belong to these land use types were not analyzed in the study. In this paper, we classified land uses based on available governmental statistics. Owing to inconsistent statistical calibers and statistical gaps for some land types, part land areas were not included in the governmental land use classification. As a result, in the paper, the total area of all land uses was smaller than the regional territory $[3,26]$. The data 
were cross-checked with the national governmental statistic yearbook and local statistics of the three administrative entities as well as a national onsite survey on cropland, forest, and wetland [27,34].

The population, GDP, industrial sector classification, and energy consumption datasets for each sector were obtained from the statistical yearbook [34,35]. We used GDP to indicate economic development.

\subsection{Monetary Valuation of Ecosystem Services}

Based on the benefit transfer method and valuation framework proposed by Costanza et al. [6], Xie et al. [14] classified the ecosystem services into 11 types for Chinese terrestrial ecosystems. They also modified the unit values of ecosystems by developing the concept of an equivalent weighting value of ecosystem services per area of ecosystem, which refers to the importance of different ecosystem services relative to food production from cultivated land; the equivalent weighting value was set as 1 [14]. The unit values of different ecosystems were quantified by multiplying their equivalent weighting values relative to food production values.

We adopted the unit value of ecosystem types described by Xie et al. [14] to calculate the ESVs (Table 1). The built-up area was not listed in the ecosystem classification because it provided no ESV. We excluded the ecosystem services of provision of food, products, and raw materials to avoid double accounting, because such values are always accounted for in the GDP in Chinese statistics [34]. For comparability, we used the 1990 price level to calculate the ESVs for all study years, and the GDPs of the study years were converted to the 1990 benchmark based on the yearly price index released by the Chinese central government [34].

In accordance with [14], the equation used to evaluate the ESVs of the region was

$$
E S V=\sum_{i=1}^{10} \sum_{j=1}^{8} P \cdot E_{i j} \cdot A_{i}
$$

where $E S V$ refers to the total ecosystem service value of all ecosystem types; $P$ is the economic value (net income) of food production by cultivated land (Yuan/ha); $E_{i j}$ is the equivalent weighting value of ecosystem service type $j$ of ecosystem type $i$, which was defined in Table 1 ; and $A_{i}$ is the area of ecosystem type $i$ (ha). 
Table 1. Ecosystem classification and equivalent weighting values for ecosystem services $[6,14]$.

\begin{tabular}{|c|c|c|c|c|c|c|c|c|c|c|}
\hline \multirow{3}{*}{$\begin{array}{c}\text { Ecosystem } \\
\text { Ecosystem Service }\end{array}$} & \multicolumn{10}{|c|}{ Ecosystem Classification and Equivalent Weighting Value } \\
\hline & \multicolumn{2}{|c|}{ Cropland } & \multicolumn{3}{|c|}{ Woodland } & \multicolumn{2}{|c|}{ Grassland } & \multicolumn{2}{|c|}{ Water Areas } & \multirow{2}{*}{$\begin{array}{l}\text { Bare Land } \\
\text { Bare Land }\end{array}$} \\
\hline & Dryland & Paddy Field & Coniferous Forest & Broadleaf Forest & Shrub & Grass & Sparse Grass & Water Body & Wetland & \\
\hline Gas regulation & 0.67 & 1.11 & 1.7 & 2.17 & 1.41 & 0.51 & 1.97 & 0.77 & 1.9 & 0.02 \\
\hline Climate regulation & 0.36 & 0.57 & 5.07 & 6.5 & 4.23 & 1.34 & 5.21 & 2.29 & 3.6 & 0 \\
\hline Environment purification & 0.1 & 0.17 & 1.49 & 1.93 & 1.28 & 0.44 & 1.72 & 5.55 & 3.6 & 0.1 \\
\hline Water regulation & 0.27 & 2.72 & 3.34 & 4.74 & 3.35 & 0.98 & 3.82 & 102.24 & 24.23 & 0.03 \\
\hline Soil retention & 1.03 & 0.01 & 2.06 & 2.65 & 1.72 & 0.62 & 2.4 & 0.93 & 2.31 & 0.02 \\
\hline Nutrient cycling & 0.12 & 0.19 & 0.16 & 0.2 & 0.13 & 0.05 & 0.18 & 0.07 & 0.18 & 0 \\
\hline Biodiversity & 0.13 & 0.21 & 1.88 & 2.41 & 1.57 & 0.56 & 2.18 & 2.55 & 7.87 & 0.02 \\
\hline Aesthetics & 0.06 & 0.09 & 0.82 & 1.06 & 0.69 & 0.25 & 0.96 & 1.89 & 4.73 & 0.01 \\
\hline
\end{tabular}




\subsection{Ecosystem Service Value Changes in Relation to Economic Development}

In this study, we employed the elasticity indicator (EI) (Equation (2)) to investigate the changes in ESVs in relation to GDP, which reflects the developmental synchronism between the two [36].

$$
\begin{gathered}
E I=E S R / G D P R \\
E S R=\left(E S V_{j}-E S V_{i}\right) / E S V_{i} \\
G D P R=\left(G D P_{j}-G D P_{i}\right) / G D P_{i}
\end{gathered}
$$

where $E I$ is the elasticity indicator, $E S V_{j}$ is the ESV at the end of year $j, E S V_{i}$ is the ESV of starting year $i$, and ESR is the growth rate of ESV. GDP $P_{j}$ is the GDP at the end of year $j$, and $G D P_{i}$ is the GDP at the start of year i. GDPR is the growth rate of GDP. According to the statistics from 1990 to 2015, GDP had an increasing trend. Therefore, the GDPR value was kept positive in this period. The implication of $E I$ below was based on having a positive GDPR value.

$E I>1$ means that the growth of ESVs is on pace with the growth of the GDP; $0<E I<1$ indicates that the GDP is increasing much faster than the ESVs, but the ESVs still have a rising trend. Within the range of 0 to $1,0.5<E I<1$ indicates a medium match; $0<E I<0.5$ is a low match between ecosystem and economy.

When $-1<E I<0$, ESVs are decreasing while GDP is increasing, suggesting a conflict between ecological and economic development; $E I<-1$ indicates a decrease in ESVs and deterioration of the ecological environment, in which there is serious conflict between the ecosystem and economy, and the development pattern is unstainable [37].

Ecological efficiency is defined as the consumption of ecosystem services per unit of economic gain [38]. In this study, the ESV was the quantified ecosystem service. We used the ecosystem service load (ESL) to represent the consumption of ESVs per unit GDP in a region to indicate the ecological efficiency in economic growth (Equation (5)).

$$
\begin{gathered}
E S L=E S L_{1} \times w_{1}+E S L_{2} \times w_{2}+E S L_{3} \times w_{3} \\
E S L_{1}=E S V_{1} / G D P_{1} \\
E S L_{2}=E S V_{2} / G D P_{2} \\
E S L_{3}=E S V_{3} / G D P_{3}
\end{gathered}
$$

where $E S L_{1}, E S L_{2}$, and $E S L_{3}$ are the ESLs of the agricultural, industrial, and service sectors, respectively; $E S V_{1}, E S V_{2}$, and $E S V_{3}$ are the ESV consumption for the three sectors, which are calculated based on the ecological footprint of each sector $[39,40] ; w_{1}, w_{2}$, and $w_{3}$ are the respective percentages of the economic output value in the total GDP from agriculture, industry, and service (Table A1, Appendix A). A lower ESL value indicates a higher ecological efficiency, meaning less ecosystem services are being consumed by a given unit of GDP.

\section{Results}

\subsection{Changes in Land Use Patterns}

In Jing-Jin-Ji, cropland is the dominant land use type ( 34\%), followed by woodland ( 17-23\%) and grassland $(\sim 16 \%)$. The other three ecosystem types-water areas, built-up land, and bare land-occupy relatively small areas. As a region of water scarcity, the water areas comprise only around 5\% in the total areas of the region; we divided water area into two types of water body and wetland. In the total water areas, water body takes 33\%, and wetland takes $67 \%$ (Figure 2 and Table A2, Appendix B). 


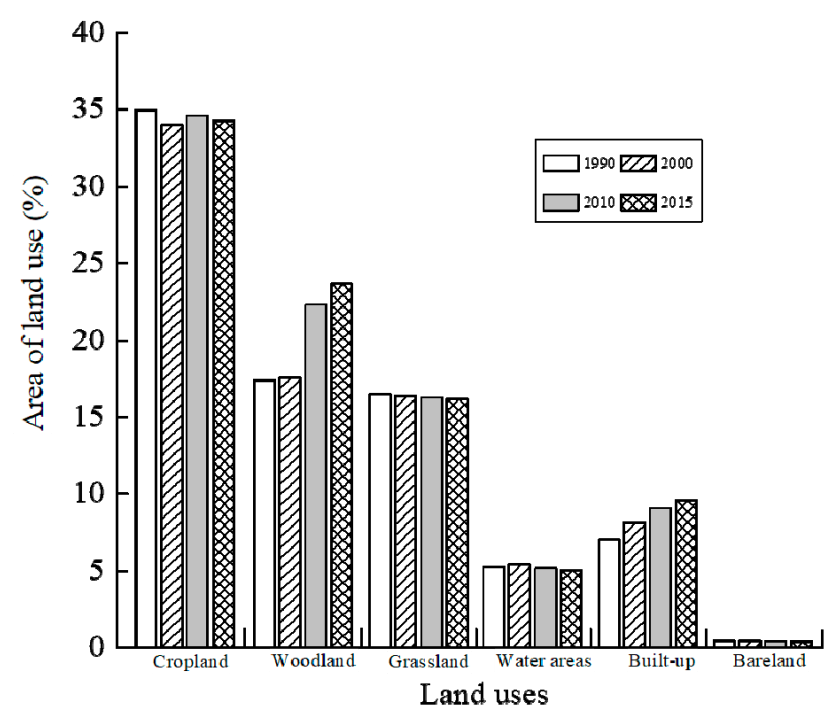

Figure 2. Areal changes in land uses from 1990 to 2015 in the Jing-Jin-Ji region.

For the period 1990-2000, the land use change featured a large decrease in cropland and a rapid increase in built-up areas; the cropland area decreased by $2100 \mathrm{~km}^{2}(2.79 \%)$, whereas the built-up area increased by $2452 \mathrm{~km}^{2}(16.25 \%)$. Over the period 2000-2010, woodland increased by $10,125 \mathrm{~km}^{2}$ $(26.75 \%)$, and the built-up area increased by $1997 \mathrm{~km}^{2}(11.39 \%)$; there was a decrease in water area of $535 \mathrm{~km}^{2}(4.61 \%)$. Over the period 2010-2015, woodland and built-up areas continued to increase, with increases of $2960 \mathrm{~km}^{2}(6.17 \%)$ and $1085 \mathrm{~km}^{2}(5.55 \%)$, respectively; the water area decreased continuously by $163 \mathrm{~km}^{2}(1.47 \%)$. From 1990 to 2015, both woodland and built-up areas increased steadily by $36.05 \%$ and $36.68 \%$, respectively, whereas the cropland, grassland, and water areas decreased by $1.91 \%, 1.87 \%$, and $3.14 \%$, respectively.

\subsection{Changes in Ecosystem Service Values}

\subsubsection{Temporal Changes in Ecosystem Service Values}

Although the woodland and water areas comprise relatively small areas of the region, the ESVs of woodland and water areas contribute to large portions of the total ESV because of their high unit ESVs. In general, woodland contributed to nearly half of the total ESV (42.7\%, on average, annually), and water areas contributed to $38.06 \%$, on average, annually; The ESVs of cropland and grassland contributed to about 19.23\% (Figure 3). There were variations in ESVs within each land use type (Table A3, Appendix B). Over the period 1990-2000, the ESVs of woodland and water areas increased slightly, whereas those of cropland and grassland decreased. Over the period 2000-2010, the increase in the ESV of woodland accelerated and achieved a sharp increase of $26.73 \%$. The ESV of cropland rose slightly; the ESV of grassland continued to decrease; and the ESV of water areas also decreased in this period. For the period 2010-2015, apart from the increase in the ESV of woodland, the ESVs of the other land uses were all in decline. Between 1990 and 2015, the ESV of woodland increased continuously by $36.09 \%$, whereas the ESVs of cropland and grassland decreased by $2.87 \%$ and $2.39 \%$, respectively. The ESV increase of woodland contributed solely to the total ESV increase in the region. 

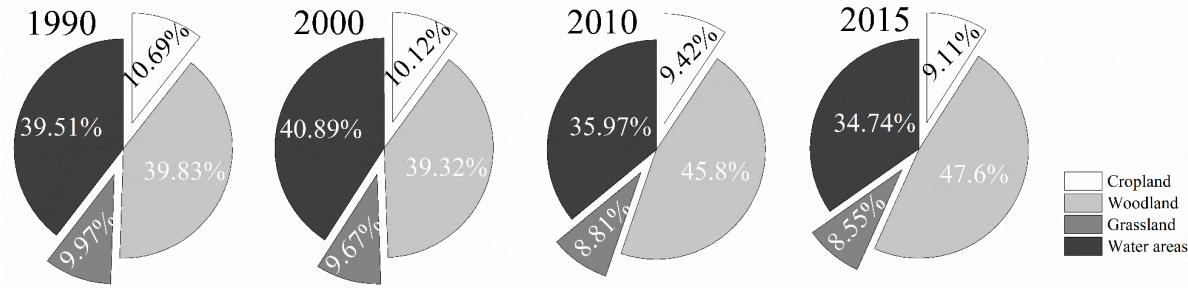

Figure 3. Contributions of ecosystem service values of each land use type to the total in the Jing-Jin-Ji region.

From a regional perspective, the total ESVs in Jing-Jin-Ji from 1990 to 2015 showed a rising trend with an increase of $13.87 \%$; in particular in the period of 2000-2010, the increase reached $8.79 \%$, which was higher than the other two periods-0.02\% for 1990-2000 and 2.14\% for 2010-2015 (Table 2). For each administrative region, the ESVs of Beijing decreased from 1990 to 2000, but after 2000, the ESVs kept rising. The ESVs of Tianjin were in decline, but the ESVs of Hebei featured an increasing trend.

Table 2. Changes in ecosystem service values (ESVs) from 1990 to 2015 in the Jing-Jin-Ji region.

\begin{tabular}{|c|c|c|c|c|c|c|c|c|}
\hline \multirow{2}{*}{$\begin{array}{c}\text { Region } \\
\text { Year }\end{array}$} & \multicolumn{2}{|c|}{ Beijing (Jing) } & \multicolumn{2}{|c|}{ Tianjin (Jin) } & \multicolumn{2}{|c|}{ Hebei (Ji) } & \multicolumn{2}{|c|}{ Jing-Jin-Ji Total } \\
\hline & $\begin{array}{c}\text { ESV } \\
\left(10^{6} \text { Yuan) }\right.\end{array}$ & $\begin{array}{l}\text { ESV/Capita } \\
\text { (Yuan) }\end{array}$ & $\begin{array}{c}\text { ESV } \\
\left(10^{6} \text { Yuan) }\right.\end{array}$ & $\begin{array}{l}\text { ESV/Capita } \\
\text { (Yuan) }\end{array}$ & $\begin{array}{c}\text { ESV } \\
\left(10^{6} \text { Yuan }\right)\end{array}$ & $\begin{array}{l}\text { ESV/Capita } \\
\text { (Yuan) }\end{array}$ & $\begin{array}{c}\text { ESV } \\
\left(10^{6} \text { Yuan }\right)\end{array}$ & $\begin{array}{l}\text { ESV } \\
(\%)\end{array}$ \\
\hline 2000 & 24,365 & 1787 & 49,164 & 4911 & 281,646 & 4220 & 355,175 & - \\
\hline 2010 & 29,633 & 1510 & 43,105 & 3318 & 313,670 & 4360 & 386,408 & - \\
\hline 2000-2010 & 5268 & -276 & -6059 & -1593 & 32,024 & 140 & 31,233 & 8.79 \\
\hline 2010-2015 & 2435 & -33 & -2721 & -707 & 8554 & -20 & 8268 & 2.14 \\
\hline 1990-2015 & 3538 & -1149 & -5255 & -2552 & 49,796 & -83 & 48,080 & 13.87 \\
\hline
\end{tabular}

The role of the ecosystem service is to sustain human wellbeing. The calculation of ecosystem services per capita has been commonly used to evaluate the ecological human wellbeing of a region [41]. In this study, we used ESV per capita $\left(\mathrm{ESV}_{\mathrm{p}}\right)$ to examine the ecological wellbeing and compare the ESV disparities in three administrative regions (Table 2). The lowest $\mathrm{ESV}_{\mathrm{p}}$ was in Beijing, and the ESV of Tianjin and Hebei province was higher. From 1990 to 2015, the ESV $\mathrm{p}$ was generally in continuous decline for the three administrative entities, with a greatly decreased value of 2552 Yuan/capita for Tianjin, 1149 Yuan/capita for Beijing, and 83 Yuan/capita for Hebei. The decreasing trend illustrates the reduced ecological wellbeing of the region with the enlarging population.

\subsubsection{Spatial Distribution of Ecosystem Service Values}

Because there was no obvious change in the spatial distribution of ESVs from 1990 to 2015, this study used the 2015 distribution as an example to explain the spatial patterns. Generally, the ESV per hectare had a gradient decline from northwest to southeast, and the lowest ESVs per hectare were seen southeast of Beijing and south of Hebei province (Figure 4). 


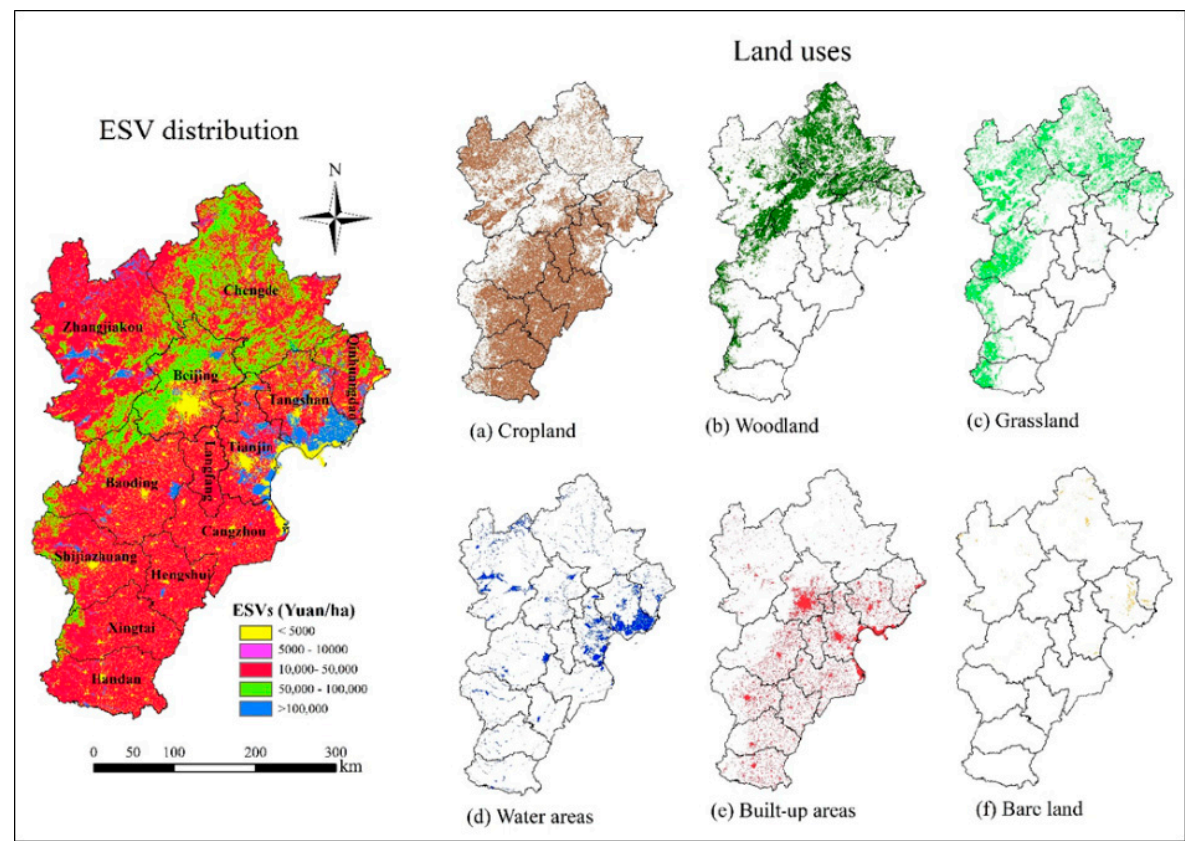

Figure 4. Spatial distribution of ecosystem service values and land uses in the Jing-Jin-Ji region.

The areas with high ESVs were positively correlated with the distribution of woodland, grassland, and water areas and were negatively correlated with the distribution of cropland and built-up land. The most eye-catching areas of highest ESVs were in the areas covered by water.

\subsection{Relationship between Ecosystem Service Values and the Local Economy}

\subsubsection{Elasticity of Growth in Ecosystem Service Values and GDP}

We examined the situation in the three administrative entities for each period to show the regional disparities (Table 3). For the period 1990-2000, the elasticity indicator (EI) of Beijing was less than 0, showing that the ESVs were in negative growth, accompanying the positive growth in GDP. There was a mismatch between the development speeds of the two. Over the periods 2000-2010 and 2010-2015, the situation improved as shown by an EI value of $0.5 \leq \mathrm{EI}<1$, suggesting a moderate match between ecological and economic development. For Tianjin, the situation was the opposite. For the period 1990-2000, the EI was $0.087(0<\mathrm{EI}<0.5)$, indicating a potential threat of the economy to ecosystem deterioration, although the ecosystem was in a rising state. For the periods 2000-2010 and 2010-2015, the situation in Tianjin worsened with EI values decreasing to -0.354 and -0.51 $(-1<\mathrm{EI}<0)$, respectively, showing that economic growth was accompanied by a decrease in ESVs. Over the whole study period (1990-2015), the EI of Hebei province continually increased from 0.045 to 0.974 , indicating that both the economy and ecosystem were growing, and that the growing pace of the ecosystem was gradually catching up with the economy.

Table 3. Elasticity indicator (EI) in the Jing-Jin-Ji region.

\begin{tabular}{cccc}
\hline \multirow{2}{*}{ Region } & \multicolumn{3}{c}{ Elasticity Indicator } \\
\cline { 2 - 4 } & $\mathbf{1 9 9 0 - 2 0 0 0}$ & $\mathbf{2 0 0 0 - 2 0 1 0}$ & $\mathbf{2 0 1 0 - 2 0 1 5}$ \\
\hline Beijing & -0.135 & 0.500 & 0.697 \\
Tianjin & 0.087 & -0.354 & -0.510 \\
Hebei & 0.045 & 0.234 & 0.974 \\
Jing-Jin-Ji average & 0.028 & 0.198 & 0.293 \\
\hline
\end{tabular}




\subsubsection{The Ecosystem Service Load}

Table 4 lists the ESL of each sector for Beijing, Tianjin, and Hebei for different years. From a sectoral perspective, generally, the ESL of the industry was the highest, followed by the agriculture and service sectors. Across the three administrative entities, the average ESL of Hebei was the highest, Tianjin was second, and the average ESL of Beijing was the lowest. The average ESL of the three administrative entities was in gradual decline over the study period; a sharp decrease was observed for the period 1990-2000, and then the decreasing rate slowed. The greatest decrease in the ESL was in Hebei province, from 3.04 in 1990 to 1.34 in 2015. The decrease in the ESL showed improved ecological efficiency per unit GDP increase.

Table 4. The ecosystem service load (ESL) from 1990 to 2015 in the Jing-Jin-Ji region.

\begin{tabular}{cccccccccc}
\hline \multirow{2}{*}{ Region } & \multirow{2}{*}{ Sectors } & \multicolumn{9}{c}{ ESL } & \multicolumn{5}{c}{ ESL Changes } \\
\cline { 3 - 9 } & & $\mathbf{1 9 9 0}$ & $\mathbf{2 0 0 0}$ & $\mathbf{2 0 1 0}$ & $\mathbf{2 0 1 5}$ & $\mathbf{1 9 9 0 - 2 0 0 0}$ & $\mathbf{2 0 0 0 - 2 0 1 0}$ & $\mathbf{2 0 1 0 - 2 0 1 5}$ & $\mathbf{1 9 9 0 - 2 0 1 5}$ \\
\hline \multirow{4}{*}{ Beijing } & Agriculture & 0.29 & 0.10 & 0.06 & 0.04 & -0.19 & -0.05 & -0.01 & -0.25 \\
& Industry & 0.78 & 0.42 & 0.29 & 0.25 & -0.38 & -0.13 & -0.05 & -0.55 \\
& Service & 0.32 & 0.13 & 0.16 & 0.19 & -0.20 & 0.04 & 0.02 & -0.14 \\
& Average & 0.57 & 0.23 & 0.20 & 0.19 & -0.34 & -0.04 & -0.01 & -0.38 \\
\hline \multirow{4}{*}{ Tianjin } & Agriculture & 0.53 & 0.28 & 0.11 & 0.08 & -0.25 & -0.17 & -0.03 & -0.45 \\
& Industry & 1.90 & 1.17 & 1.05 & 1.03 & -0.73 & -0.12 & -0.01 & -0.87 \\
& Service & 1.10 & 0.60 & 0.20 & 0.15 & -0.49 & -0.40 & -0.05 & -0.95 \\
& Average & 1.52 & 0.87 & 0.57 & 0.47 & -0.65 & -0.30 & -0.09 & -1.05 \\
\hline \multirow{6}{*}{ Hebei } & Agriculture & 0.81 & 0.23 & 0.10 & 0.08 & -0.57 & -0.13 & -0.02 & -0.73 \\
& Industry & 6.10 & 3.99 & 3.48 & 3.95 & -2.11 & -0.51 & 0.47 & -2.15 \\
& Service & 0.63 & 0.45 & 0.46 & 0.56 & -0.18 & 0.01 & 0.10 & -0.07 \\
& Average & 3.04 & 1.79 & 1.34 & 1.34 & -1.25 & -0.45 & 0.00 & -1.7 \\
\hline
\end{tabular}

Although the ESL was in overall decline for Jing-Jin-Ji, the intraregional disparities in ESL were amplified over the years. In 1990, the average ESL of Hebei was approximately five times higher than that of Beijing, which was amplified to seven times higher in 2015. Similarly, the average ESL of Hebei was approximately two times higher than that of Tianjin, and this value approached a level three times higher in 2015. The average ESL gap between Tianjin and Beijing remained at the same level as Tianjin, approximately 2.7 times more than that of Beijing. The results indicate that the ecological efficiency of Hebei lagged far behind Beijing and Tianjin.

The average ESL was determined from the ESL of each sector and the GDP share of each sector of the total GDP (Equation (5)). The economic structure was shown to largely impact the ESL in the region. In Beijing, the GDP of the service sector accounted for 39\% in 1990, and this proportion was increased to $80 \%$ in 2015 (Figure 5). Compared to Tianjin and Hebei, the ESL of each sector was lower, and the service sector, which had the lowest ESL, contributed to a large proportion of the total GDP in Beijing. Therefore, the average ESL of Beijing was the lowest, which indicates the high ecological efficiency that is present in Beijing. Conversely, in Hebei province, industry contributed to approximately half the GDP, and the ESL of industry in Hebei was much higher-approximately 15 times higher than Beijing and four times higher than Tianjin in 2015. Therefore, the average ESL of Hebei was the highest. In Tianjin, the GDP contributed by industry decreased from $60 \%$ in 1990 to $47 \%$ in 2015, whereas that of service increased from $30 \%$ to $52 \%$. Although a great portion of the GDP came from the industry sector, the average ESL of Tianjin was still lower than that of Hebei province owing to the lower ESL of its industry sector and the increased GDP contribution from the service sector. 


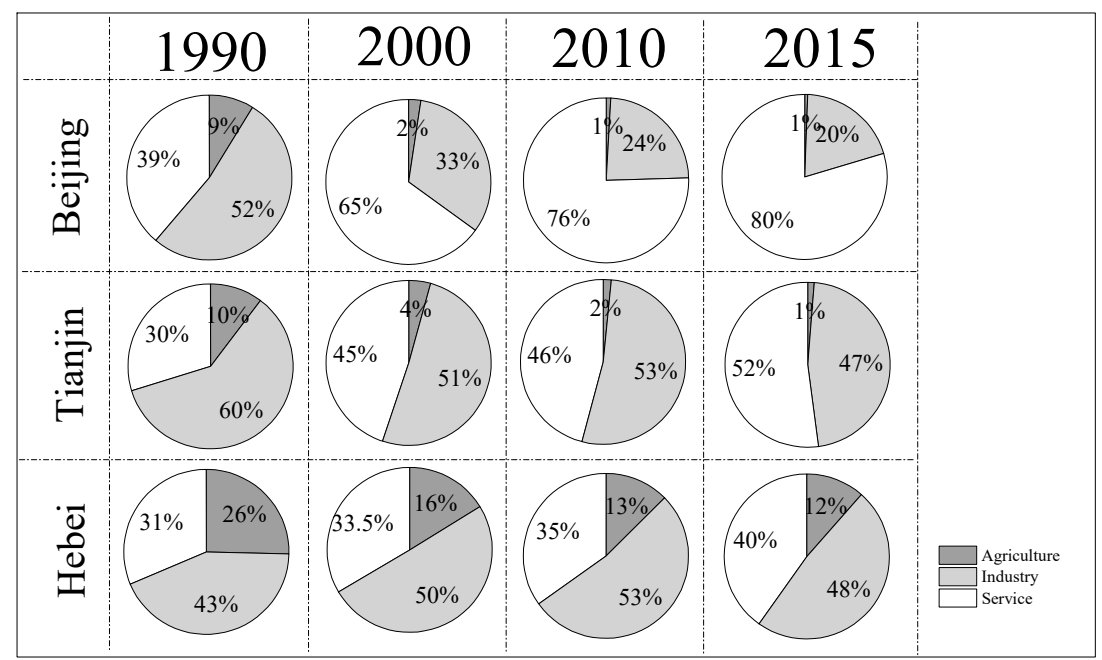

Figure 5. Gross domestic product (GDP) compositions of Beijing, Tianjin, and Hebei.

\section{Discussion}

\subsection{Comparison of Ecosystem Service Values of Jing-Jin-Ji to Other Studies}

Some ESV studies have focused on the capital circle region. Zhang et al. [42] showed the spatial distribution of ESVs in the region. They concluded that the highest ESVs ( $>80,000$ Yuan/ha) were concentrated in the coastal areas of Tianjin city and Tangshan city of Hebei province. The relatively higher ESVs (20,000-80,000 Yuan/ha) found in the north and west of the region, areas covered mainly by woodland and grassland. The low ESVs (5000-10,000 Yuan/ha) were concentrated in the Southeastern plains, which are covered by agriculture and residential areas. Our results (Figure 4) are basically consistent with the spatial distribution drawn from Zhang et al.'s study.

Xie et al. [14] estimated the national ESVs using the 2010 prices and concluded that the value of forests accounted for the largest proportion (46\%), followed by water areas (21.16\%), and grassland $(19.68 \%)$. In our study, similar to the national level, the ESV of woodland in Jing-Jin-Ji contributed to $45.8 \%$ of the total ESV; the ESV of water areas contributed to $35.97 \%$, higher than the national level. The ESV of grassland accounted for only $8.81 \%$, much lower than the national level. The differences mainly resulted from the different coverage rates of land use between the national level and the Jing-Jin-Ji regional level. The coverage rates of woodland, grassland, and water areas in 2010 at the national level were $23.64 \%, 31.56 \%$, and $2.91 \%$, respectively [43], but the corresponding coverage rates in Jing-Jin-Ji were $22.29 \%, 16.28 \%$, and $5.51 \%$. The coverage rate of woodland in Jing-ji-Ji was close to the national level, but the grassland rate was lower, and the water area rate was higher than the national level.

Xie et al. [14] showed that, in 2010, the national ESV per capita was 28,400 Yuan and the GDP per capita was 29,900 Yuan. Based on the 2010 price, this study found that the ESV per capita in Jing-Jin-Ji was 10,329 Yuan, and the GDP per capita was 41,828 Yuan. Because more than 50\% GDP was generated by the service sector, despite having a lower ESV per capita, the Jing-Jin-Ji region achieved a much higher GDP per capita than the country average. The results implied a higher ecological efficiency in the region.

\subsection{Response of Ecosystem Service Values to Land Use Changes}

Driven by the economic priority development policy before 2000, there was a massive increase in built-up areas in association with industrial sprawl, increasing urbanization, and development of rural nonagricultural activities [44,45]. Consequently, between 1990 and 2000, the ESV growth by areal increase in water area was offset by the increased built-up area and decreased cropland and grassland areas. Since 1998, faced with severe ecological degradation and its induced tremendous social and 
economic costs, the Chinese government has vowed to rehabilitate and restore the ecosystem by releasing ecologically friendly policies. Remarkable examples include the "grain for green project" that returns farmlands to forests and the "Beijing-Tianjin sandstorm control" that built a sand prevention ecological circle surrounding Beijing and Tianjin [2,3]. Under the effects of those polices, a higher increase $(8.79 \%)$ in the total ESV resulted from the areal increase of woodland during the 2000-2010 period. During the 2010-2015 period, the rate of increase in woodland slowed; the water area was in decline owing to natural evaporation and poor water conservation schemes [27]. In the meantime, the grassland area continued to decrease. In response to this land use change pattern, the ESV increased by only $2.14 \%$. Over the whole study period, the increase in ESV in Jing-Jin-Ji was mainly contributed by the areal increase of woodland, and the decrease in ESV was mainly ascribed to the decreased areas of water, grassland, and cropland, most of which was replaced by built-up areas with no ESV due to increasing urbanization [46].

Land use changes reflect the impacts of human activities on ecosystems that accelerate the changes in ESVs. Areal changes in land use types that provide a high ESV can exert great influences on the total ESV variation. As illustrated in Table 2, the land use pattern in the Jing-Jin-Ji region had the following features: the dominant land use was cropland of low unit ESV; the built-up areas providing no ESV were enlarged; the total areas taken by the high unit ESV land uses of woodland, water areas, and grassland were less than $40 \%$, and this proportion was still decreasing because of ecological degradation and urbanization. Within this context, an efficient way to improve ecosystem services is to enhance conservation policies, such as forest protection projects, grassland and wetland conservation, and restoration $[26,47,48]$. In addition, with the increasing urbanization, more attention should be given to ecological urban construction, replacing functions of "gray" infrastructure with "green" infrastructure with ecological functions, such as natural or constructed wetlands, forest patches, and vegetation belts $[49,50]$.

\subsection{Moving Forward towards Mutual Sustainability of the Ecosystem and Economy}

The sustainable development of a region requires a state of increasing overall economy under the insurance of social stability while maintaining synchronous economic and ecosystem growth [25]. Achieving balance between the ecosystem and economy in a region requires an acceleration of the increase in ecosystem services within the economic development (improve EI) and a reduction in the occupation of ecological resources in economic growth (lower the ESL).

Alongside China's economic takeoff, Jing-Jin-Ji also underwent rapid economic development. For the period 1990-2000, which was dominated by economic benefits only, the ecosystem was neglected in terms of GDP growth. According to the EI analysis (Table 3), there was a great mismatch between the development speed of ESVs and the GDP, and the situation in Beijing was even worse. With the enhanced conservation efforts in China during the periods of 2000-2010 and 2010-2015, the situation in Beijing and Hebei improved to a moderate match between the development paces of ESVs and GDP; however, a great mismatch was still found in Tianjin. The results suggest that actions should be enhanced to support ecological development, e.g., the promotion of cooperative efforts between scientific research, public engagement, and governance to parallel the ecological development in economic growth, and the incorporation of ecological performance into the official performance evaluation across all governmental levels.

The ecological deterioration was mainly induced by excessive ecological consumption for economic development, which was linked closely with the ecological condition and ecological efficiency. The analyses of $\operatorname{ESV}_{\mathrm{p}}$ (Table 2) and ESL for the three administrative entities (Table 4) showed that the differences in ecological wellbeing and ecological efficiency were mainly induced by local ecological resources, population size, industrial structures, and technology levels. The ecological efficiency was highest for Beijing and improved from 1990 to 2015 . However, the ecological wellbeing worsened owing to the lack of ecological resources and an increased population. Therefore, it is important to control the population size of Beijing, evacuate its multiple functions, and relocate the 
heavy industries, as planned in the "Jing-Jin-Ji coordinated development strategy" [36]. For Tianjin, the updated economic structure contributed to the relief of ecological pressure. However, the ecological deterioration has continued, especially with damage to coastal wetland areas [30,51]. Furthermore, industry, which has a high ESL, still comprised nearly half of the total GDP. Therefore, attention should be given to the structural transition and updates of industry and wetland conservation in Tianjin. There were more ecological resources in Hebei province compared to Beijing and Tianjin because of its large area. However, its development was dependent on the extensive use of energy and ecological resources, which have threatened the sustainability of the ecological environment [52]. Investments in technological innovation, industry updates, and economic structure adjustment should be reinforced.

It should be pointed out that the level of ecological efficiency in Hebei may never catch up to that of Beijing and Tianjin because of their different economic structures and urbanization levels [28,29]. Among the three administrative entities, the economically less developed Hebei is the ecosystem service supplier. National ecosystem management strategies have considered a transfer payment arrangement that regulates economic interests among ecological protectors, beneficiaries, and destructors [53-55]. To date, apart from national transfer payment scheme from the central government to poor and remote regions, there is only one intraregional payment for ecosystem service (PES) scheme between Beijing and Hebei for the provision of clean water over the past ten years [56]. Therefore, a comprehensive PES scheme is needed to help achieve balanced economic and ecological development in Jing-Jin-Ji. PES provides the demander with transferable ecosystem services like goods provision, for some services that are not transferable, like flood regulation and soil retention, can only be owned locally. To achieve local ecological sustainability, in situ ecological conservation is crucial and should be given high priority.

\subsection{Limitations of This Study}

In this paper, we adopted the benefit transfer method for ESV calculation [6,14]. It transfers the relative importance of different ecosystem services to the economic value per unit area. ESVs were measured based on a comparison with the value of food production. Thus, when the ecosystem services of a region were determined, their importance was easily reflected by their ESV. This valuation method has been widely applied to investigate local ecosystem value changes under different land uses [18,57]. However, the robustness of the valuation results is still a great concern of many scholars [58,59]. For example, the equivalent weighting value assigned to each land use is based on questionnaires and the results may differ among interviewees. The other shortcoming is that it assigns a given land use the same value with no consideration of difference in land quality. In reality, for a given land use, the difference in quality can result in ESV differences, e.g., clean water provides a high ESV, whereas polluted water not only provides less or no ESV but impedes the water supply, causes oxygen depletion, and even kills aquatic life [60,61]. In future research, special concern should be given to the impact of ecosystem quality on its services [62]. More work is required to improve ESV evaluation, such as the site-to-site investigation of ecosystems and cross-checking the ESV results with those measured by other methods. The ESVs obtained in this study may deviate from the actual situation, but they can still reflect the time series changes in ecosystem services under different land uses and the dynamic relations between the ecosystem and economic development.

\section{Conclusions}

Different developmental patterns under the three phases in China have had significant impacts on the regional ESVs and the interactions between ESVs and GDP. From 1990 to 2015, the ESV of woodland in Jing-Jin-Ji continuously increased as a result of forest protection projects that increased the woodland area. The ESVs of cropland, grassland, and water areas decreased over the study period as these land use areas were converted to built-up areas. Therefore, multiple conservation actions for grassland and water areas and ecological urbanization measures should be enhanced. 
We used EI and ESL to investigate the interactions between ecosystem services and the economy. The results showed that the growth of ecosystem services has been relatively balanced with economic development, and the ecological efficiency improved gradually over the study period. Within the region, large disparities were observed for Beijing, Tianjin, and Hebei. The EI of Beijing evolved from -0.135 between 1990 and 2000 to 0.697 between 2010 and 2015; its ESL improved from 0.57 in 1990 to 0.19 in 2015. This demonstrated that the growth rates of ESVs and GDP were increasingly matched, and the ecosystem efficiency greatly improved in Beijing. Compared to the period 1990-2000, the EI of Tianjin decreased to -0.51 by the period 2010-2015, showing that its ESV growth lagged far behind economic growth. The changes in the EI and ESL in Hebei over the study period showed that its ecological development was catching up with its economic growth, and its ecological efficiency improved. Nevertheless, its ecological efficiency was still far behind that of Beijing and Tianjin. In view of the features captured for Beijing, Tianjin, and Hebei, specific measures can be taken for each of the three administrative entities. For example, emphasis should be placed on defining the city function and controlling the population influx in Beijing. For Tianjin, coastal wetland conservation and industry updates should be enhanced. In addition to ecological conservation, there is an urgent need for industrial structures to be adjusted and technology to be improved in Hebei province. Moreover, the public and private sectors should cooperate on the intraregional PES mechanism to narrow the regional disparities.

Author Contributions: Conceptualization, S.L. and G.L.; Data Curation, S.L., G.L. and H.Y.; Methodology, S.L. and G.L; Validation, S.L., H.Y., J.L. and G.L.; Formal Analysis, S.L.,H.Y., J.L. and G.L.; Investigation, S.L., and G.L.; Resources, S.L., J.L., and G.L.; Writing-Original Draft Preparation, S.L.; Writing-Review and Editing, S.L., H.Y., J.L. and G.L.; Visualization, S.L.; Supervision, H.Y., J.L. and G.L.; Project Administration, G.L.; Funding Acquisition, J.L., and G.L.

Funding: This research was funded by the National Natural Science Foundation of China $(41625001,41571022)$.

Acknowledgments: The authors would like to thank the editors of the journal and the reviewers for their time and constructive comments, which have significantly improved the quality of our manuscript.

Conflicts of Interest: The authors declare no conflict of interest.

Appendix A. Weight of the Ecosystem Service Load (ESL) Allocated to the Agricultural, Industrial, and Service Sectors, Respectively

Table A1. Weight of the ecosystem service load for each sector.

\begin{tabular}{cccccc}
\hline Region & Weight & $\mathbf{1 9 9 0}$ & $\mathbf{2 0 0 0}$ & $\mathbf{2 0 1 0}$ & $\mathbf{2 0 1 5}$ \\
\hline \multirow{3}{*}{ Beijing } & $w_{1}$ & 0.088 & 0.024 & 0.009 & 0.006 \\
& $w_{2}$ & 0.524 & 0.326 & 0.236 & 0.198 \\
& $w_{3}$ & 0.388 & 0.650 & 0.756 & 0.796 \\
\hline \multirow{3}{*}{ Tianjin } & $w_{1}$ & 0.102 & 0.043 & 0.016 & 0.013 \\
& $w_{2}$ & 0.599 & 0.508 & 0.525 & 0.466 \\
& $w_{3}$ & 0.298 & 0.449 & 0.460 & 0.522 \\
\hline \multirow{3}{*}{ Hebei } & $w_{1}$ & 0.254 & 0.162 & 0.126 & 0.115 \\
& $w_{2}$ & 0.432 & 0.503 & 0.525 & 0.483 \\
& $w_{3}$ & 0.313 & 0.335 & 0.349 & 0.402 \\
\hline
\end{tabular}




\section{Appendix B. Details of Land Use Changes and Changes in Ecosystem Service Values (ESVs)}

Table A2. Areal changes in land use from 1990 to 2015 in the Jing-Jin-Ji region.

\begin{tabular}{ccccccccccccc}
\hline Land Use & \multicolumn{2}{c}{ Cropland } & \multicolumn{2}{c}{ Woodland } & \multicolumn{2}{c}{ Grassland } & \multicolumn{2}{c}{ Water areas } & \multicolumn{2}{c}{ Built-up } & \multicolumn{2}{c}{ Bare land } \\
\hline Area & $\mathbf{k m}^{\mathbf{2}}$ & $\mathbf{\%}$ & $\mathbf{k m}^{\mathbf{2}}$ & $\mathbf{\%}$ & $\mathbf{k m}^{\mathbf{2}}$ & $\mathbf{\%}$ & $\mathbf{k m}^{\mathbf{2}}$ & $\mathbf{\%}$ & $\mathbf{k m}^{\mathbf{2}}$ & $\mathbf{\%}$ & $\mathbf{k m}^{\mathbf{2}}$ & $\mathbf{\%}$ \\
\hline 1990 & 75,272 & 34.97 & 37,435 & 17.39 & 35,464 & 16.48 & 11,273 & 5.24 & 15,086 & 7.01 & 928 & 0.43 \\
2000 & 73,172 & 33.99 & 37,845 & 17.58 & 35,298 & 16.40 & 11,617 & 5.40 & 17,538 & 8.15 & 931 & 0.43 \\
2010 & 74,494 & 34.61 & 47,970 & 22.29 & 35,051 & 16.28 & 11,082 & 5.15 & 19,535 & 9.08 & 880 & 0.41 \\
2015 & 73,832 & 34.30 & 50,930 & 23.66 & 34,801 & 16.17 & 10,919 & 5.07 & 20,620 & 9.58 & 864 & 0.40 \\
$1990-2000$ & -2100 & -2.79 & 3073 & 1.10 & -165 & -0.47 & 345 & 3.06 & 2452 & 16.25 & 3 & 0.30 \\
$2000-2010$ & 1322 & 1.81 & 10,125 & 26.75 & -248 & -0.70 & -535 & -4.61 & 1997 & 11.39 & -51 & -5.48 \\
$2010-2015$ & -662 & -0.89 & 2960 & 6.17 & -249 & -0.71 & -163 & -1.47 & 1085 & 5.55 & -16 & -1.80 \\
$1990-2015$ & -1440 & -1.91 & 16,158 & 36.05 & -663 & -1.87 & -353 & -3.14 & 5534 & 36.68 & -64 & -6.9 \\
\hline
\end{tabular}

Table A3. Changes in ecosystem service values (ESVs) for each land use type from 1990 to 2015 in the Jing-Jin-Ji region.

\begin{tabular}{|c|c|c|c|c|c|c|c|c|c|c|c|c|}
\hline \multirow{2}{*}{$\begin{array}{c}\text { Land Use } \\
\text { ESVs }\end{array}$} & \multicolumn{2}{|c|}{ Cropland } & \multicolumn{2}{|c|}{ Woodland } & \multicolumn{2}{|c|}{ Grassland } & \multicolumn{2}{|c|}{ Water Areas } & \multicolumn{2}{|c|}{ Bare Land } & \multicolumn{2}{|c|}{ Total } \\
\hline & $\begin{array}{c}10^{6} \\
\text { Yuan }\end{array}$ & $\%$ & $\begin{array}{c}10^{6} \\
\text { Yuan }\end{array}$ & $\%$ & $\begin{array}{c}10^{6} \\
\text { Yuan }\end{array}$ & $\%$ & $\begin{array}{c}10^{6} \\
\text { Yuan }\end{array}$ & $\%$ & $\begin{array}{c}10^{6} \\
\text { Yuan }\end{array}$ & $\%$ & $\begin{array}{c}10^{6} \\
\text { Yuan }\end{array}$ & $\%$ \\
\hline 1990 & 37,030 & 10.68 & 138,044 & 39.83 & 34,553 & 9.97 & 136,936 & 39.51 & 33 & 0.01 & 346,596 & - \\
\hline 2000 & 35,954 & 10.12 & 139,647 & 39.32 & 34,330 & 9.67 & 145,211 & 40.88 & 33 & 0.01 & 355,175 & - \\
\hline 2010 & 36,379 & 9.41 & 176,970 & 45.80 & 34,045 & 8.81 & 138,984 & 35.97 & 31 & 0.01 & 386,408 & - \\
\hline 2015 & 35,966 & 9.11 & 187,867 & 47.60 & 33,726 & 8.55 & 137,087 & 34.73 & 30 & 0.01 & 394,676 & - \\
\hline $1990-2000$ & -1076 & -2.91 & 1603 & 1.16 & -222 & -0.64 & 8275 & 6.04 & 0 & 0.30 & 8579 & 0.02 \\
\hline 2000-2010 & 425 & 1.18 & 37,323 & 26.73 & -285 & -0.83 & -6227 & -4.29 & -2 & -5.48 & 31,233 & 8.79 \\
\hline 2010-2015 & -413 & -1.13 & 10,897 & 6.16 & -320 & -0.94 & -1896 & -1.36 & -1 & -1.80 & 8268 & 2.14 \\
\hline $1990-2015$ & -1064 & -2.87 & 49,822 & 36.09 & -827 & -2.39 & 151 & 0.11 & -2 & -6.9 & 48,080 & 13.87 \\
\hline
\end{tabular}

\section{References}

1. Butchart, S.H.M.; Walpole, M.; Collen, B.; van Strien, A.; Scharlemann, J.P.W.; Almond, R.E.A.; Baillie, J.E.M.; Bomhard, B.; Brown, C.; Bruno, J.; et al. Global Biodiversity: Indicators of Recent Declines. Science 2010, 328, 1164-1168. [CrossRef] [PubMed]

2. Liu, J.; Li, S.; Ouyang, Z.; Tam, C.; Chen, X. Ecological and socioeconomic effects of China's policies for ecosystem services. Proc. Natl. Acad. Sci. USA 2008, 105, 9477-9482. [CrossRef] [PubMed]

3. Yang, H. Land conservation campaign in China: Integrated management, local participation and food supply option. Geoforum 2004, 35, 507-518. [CrossRef]

4. De Groot, R.S.; Wilson, M.A.; Boumans, R.M. A typology for the classification, description and valuation of ecosystem functions, goods and services. Ecol. Econ. 2002, 41, 393-408. [CrossRef]

5. Hein, L.; Koppen, K.V.; Groot, R.S.D.; Ierland, E.C.V. Spatial scales, stakeholders and the valuation of ecosystem services. Ecol. Econ. 2006, 57, 209-228. [CrossRef]

6. Costanza, R.; d'Arge, R.; De Groot, R.; Farber, S.; Grasso, M.; Hannon, B.; Limburg, K.; Naeem, S.; O'neill, R.V.; Paruelo, J. The value of the world's ecosystem services and natural capital. Nature 1997, 387, $253-260$. [CrossRef]

7. Daily, G.C.; Matson, P.A. Ecosystem services: From theory to implementation. Proc. Natl. Acad. Sci. USA 2008, 105, 9455-9456. [CrossRef] [PubMed]

8. Millennium Ecosystem Assessment (MEA). Ecosystems and Human Well-Being: Synthesis; World Resources Institute: Washington, DC, USA, 2005; pp. 77-101.

9. TEEB Synthesis. Main-Streaming the Economics of Nature: A Synthesis of the Approach, Conclusions and Recommendations of TEEB; Earthscan: London, UK; Washingon, DC, USA, 2010.

10. Costanza, R.; de Groot, R.; Sutton, P.; van der Ploeg, S.; Anderson, S.J.; Kubiszewski, I.; Farber, S.; Turner, R.K. Changes in the global value of ecosystem services. Glob. Environ. Chang. 2014, 26, 152-158. [CrossRef]

11. de Groot, R.; Brander, L.; van der Ploeg, S.; Costanza, R.; Bernard, F.; Braat, L.; Christie, M.; Crossman, N.; Ghermandi, A.; Hein, L.; et al. Global estimates of the value of ecosystems and their services in monetary units. Ecosyst. Serv. 2012, 1, 50-61. [CrossRef] 
12. Ouyang, Z.; Wang, X.; Miao, H. A primary study on Chinese terrestrial ecosystem services and their ecological-economic values. Acta Ecol Sin. 1999, 19, 607-613. (In Chinese)

13. Xie, G.D.; Zhen, L.; Lu, C.-X.; Xiao, Y.; Chen, C. Expert Knowledge Based Valuation Method of Ecosystem Services in China. J. Nat. Resour. 2008, 23, 911-919.

14. Xie, G.; Zhang, C.; Zhang, C.; Zhang, C. The value of ecosystem services in China. Resour. Sci. 2015, 37, $1740-1746$.

15. Wang, X.; Dong, X.; Liu, H.; Wei, H.; Fan, W.; Lu, N.; Xu, Z.; Ren, J.; Xing, K. Linking land use change, ecosystem services and human well-being: A case study of the Manas River Basin of Xinjiang, China. Ecosyst. Serv. 2017, 27, 113-123. [CrossRef]

16. Li, H.L.; Wang, S.L.; Ji, G.L.; Zhang, L. Changes in land use and ecosystem service values in Jinan, China. Energy Procedia 2011, 5, 1109-1115.

17. Fei, L.; Zhang, S.; Yang, J.; Chang, L.; Yang, H.; Bu, K. Effects of land use change on ecosystem services value in West Jilin since the reform and opening of China. Ecosyst. Serv. 2018, 31, 12-20. [CrossRef]

18. Song, W.; Deng, X. Land-use/land-cover change and ecosystem service provision in China. Sci. Total Environ. 2017, 576, 705-719. [CrossRef] [PubMed]

19. Wilkerson, M.L.; Mitchell, M.G.E.; Shanahan, D.; Wilson, K.A.; Ives, C.D.; Lovelock, C.E.; Rhodes, J.R. The role of socio-economic factors in planning and managing urban ecosystem services. Ecosyst. Serv. 2018, 31, 102-110. [CrossRef]

20. Braat, L.C.; Groot, R.D. The ecosystem services agenda:bridging the worlds of natural science and economics, conservation and development, and public and private policy. Ecosyst. Serv. 2012, 1, 4-15. [CrossRef]

21. Mao, G.; Xia, J.; He, X.; Tang, Y.; Liu, J. Hydrology in a coupled human-natural system: Research, innovation, and practices. Bull. Am. Meteorol. Soc. 2017, 98, ES295-ES298. [CrossRef]

22. Ouyang, Z.; Zheng, H.; Xiao, Y.; Polasky, S.; Liu, J.; Xu, W.; Wang, Q.; Zhang, L.; Xiao, Y.; Rao, E.M.; et al. Improvements in ecosystem services from investments in natural capital. Science 2016, 352, 1455-1459. [CrossRef] [PubMed]

23. Li, T.; Ding, Y. Spatial disparity dynamics of ecosystem service values and GDP in Shaanxi Province, China in the last 30 years. PLoS ONE 2017, 12, 20. [CrossRef] [PubMed]

24. Li, G.; Fang, C. Global mapping and estimation of ecosystem services values and gross domestic product: A spatially explicit integration of national 'green GDP' accounting. Ecol. Indic. 2014, 46, 293-314. [CrossRef]

25. Zhang, J.J.; Fu, M.C.; Zeng, H.; Geng, Y.H.; Hassani, F.P. Variations in Ecosystem Service Values and Local Economy in Response to Land Use: A Case Study of Wu'an, China. Land Degrad. Dev. 2013, 24, 236-249. [CrossRef]

26. Li, S.; Yang, H.; Lacayo, M.; Liu, J.; Lei, G. Impacts of Land-Use and Land-Cover Changes on Water Yield: A Case Study in Jing-Jin-Ji, China. Sustainability 2018, 10, 960. [CrossRef]

27. State Forestry Administration (SFA). China Wetlands Resources; China Forestry Press: Beijing, China, 2015.

28. Mao, H. Innovation of mechanism and regional policy for promoting coordinated development of Beijing-Tianjin-Hebei. Prog. Geogr. 2017, 36, 2-14.

29. Wang, S.; Ma, H.; Zhao, Y. Exploring the relationship between urbanization and the eco-environment-A case study of Beijing-Tianjin-Hebei region. Ecol. Indic. 2014, 45, 171-183. [CrossRef]

30. He, Q.; Bertness, M.D.; Bruno, J.F.; Li, B.; Chen, G.; Coverdale, T.C.; Altieri, A.H.; Bai, J.; Sun, T.; Pennings, S.C.; et al. Economic development and coastal ecosystem change in China. Sci. Rep. 2014, 4, 5995. [CrossRef] [PubMed]

31. Liu, J.; Yang, W. Integrated assessments of payments for ecosystem services programs. Proc. Natl. Acad. Sci. USA 2013, 110, 16297-16298. [CrossRef] [PubMed]

32. Zhang, Z.; Shi, M.; Yang, H. Understanding Beijing's water challenge: A decomposition analysis of changes in Beijing's water footprint between 1997 and 2007. Environ. Sci. Technol. 2012, 46, 12373-12380. [CrossRef] [PubMed]

33. Liu, J.; Zhang, Z.; Xu, X.; Kuang, W.; Zhou, W.; Zhang, S.; Li, R.; Yan, C.; Yu, D.; Wu, S.; et al. Spatial patterns and driving forces of land use change in China during the early 21st century. J. Geogr. Sci. 2010, 20, 483-494. (In Chinese) [CrossRef]

34. National Bureau of Statistics of China (NBSC). China Statistical Yearbook; China Statistics Press: Beijing, China, 2016. Available online: http:/ / www.stats.gov.cn/tjsj/ndsj/ (accessed on 26 September 2018). (In Chinese) 
35. Hebei Statistic Bureau (HBTJ). Hebei Economic Statistical Yearbook; China Statistics Press: Beijing, China, 2016. Available online: http:/ /www.hetj.gov.cn/res/nj2016/indexch.htm (accessed on 15 November 2017). (In Chinese)

36. Sun, W.; Miao, Z.; Sun, W. Change in the Value of Ecosystem Services of Beijing-Tianjin-Hebei Area and Its Relationship with Economic Growth. Ecol. Econ. 2015, 31, 59-62. (In Chinese)

37. Wu, J.Z.; Li, B.; Zhang, X.S. Ecosystem service value and its aplication in evaluation of eco-economic harmonious development. Chin. J. Appl. Ecol. 2007, 18, 2554-2558. (In Chinese)

38. Zang, Z.; Zou, X.; Wu, L.; Song, Q.; Wu, X.; Yu, W. Evaluation of ecological well-being and eco-economic efficiency in the Chinese mainland:From the perspective of justice and efficiency. Acta Ecol. Sin. 2017, 37, 2403-2414. (In Chinese)

39. Liu, J.X.; Wang, Q.; Gu, X.W.; Li, G.J. Input-output analysis in application to study on China's ecological footprints. J. Northeast. Univ. 2007, 28, 592-595.

40. World Wide Fund for Nature (WWF). China Ecological Footprint Report; WWF: Gland, Switzerland, 2012.

41. Guerry, A.D.; Polasky, S.; Lubchenco, J.; Chaplin-Kramer, R.; Daily, G.C.; Griffin, R.; Ruckelshaus, M.; Bateman, I.J.; Duraiappah, A.; Elmqvist, T. Natural capital and ecosystem services informing decisions: From promise to practice. Proc. Natl. Acad. Sci. USA 2015, 112, 7348-7355. [CrossRef] [PubMed]

42. Zhang, B.; Xu, J.; Wang, S.; Li, N. Regional differences in land cover and ecosystem services in Capital Eco-sphere. Resour. Sci. 2015, 37, 7.

43. Liu, J.; Kuang, W.; Zhang, Z.; Xu, X.; Qin, Y.; Ning, J.; Zhou, W.; Zhang, S.; Li, R.; Yan, C.; et al. Spatiotemporal characteristics, patterns, and causes of land-use changes in China since the late 1980s. J. Geogr. Sci. 2014, 24, 195-210. (In Chinese) [CrossRef]

44. Hu, Q.L.; Qi, Y.Q.; Hu, Y.C.; Zhang, Y.C.; Wu, C.B.; Zhang, G.L. Changes and driving forces of land use/cover and landscape patterns in Beijing-Tianjin-Hebei region. Chin. J. Eco-Agric. 2011, 19, 1182-1189. (In Chinese) [CrossRef]

45. Han, Z.; Song, W.; Deng, X.; Xu, X. Trade-Offs and Synergies in Ecosystem Service within the Three-Rivers Headwater Region, China. Water 2017, 9, 588. [CrossRef]

46. Xie, W.; Huang, Q.; He, C.; Zhao, X. Projecting the impacts of urban expansion on simultaneous losses of ecosystem services: A case study in Beijing, China. Ecol. Indic. 2018, 84, 183-193. [CrossRef]

47. Xu, W.H.; Xiao, Y.; Zhang, J.J.; Yang, W.; Zhang, L.; Hull, V.; Wang, Z.; Zheng, H.; Liu, J.G.; Polasky, S.; et al. Strengthening protected areas for biodiversity and ecosystem services in China. Proc. Natl. Acad. Sci. USA 2017, 114, 1601-1606. [CrossRef] [PubMed]

48. Bai, Y.; Ouyang, Z.; Hua, Z.; Xu, W.; Zhang, C.; Zhuang, C.; Chen, S.; Jiang, B. Ecosystems patterns and dynamics in Haihe river basin. Acta Ecol. Sin. 2010, 30, 327-334.

49. Sandifer, P.A.; Sutton-Grier, A.E.; Ward, B.P. Exploring connections among nature, biodiversity, ecosystem services, and human health and well-being: Opportunities to enhance health and biodiversity conservation. Ecosyst. Serv. 2015, 12, 1-15. [CrossRef]

50. Palmer, M.A.; Liu, J.; Matthews, J.H.; Mumba, M.; D'odorico, P. Manage water in a green way. Science 2015, 349, 584-585. [CrossRef] [PubMed]

51. State Forestry Admistration (SFA). Wetland Resources in Tianjin; China Forestry Press: Beijing, China, 2015.

52. Liu, J.; Zhao, X.; Yang, H.; Liu, Q.; Xiao, H.; Cheng, G. Assessing China's "developing a water-saving society" policy at a river basin level: A structural decomposition analysis approach. J. Clean. Prod. 2018, 190, 799-808. [CrossRef]

53. Zhen, L.; Zhang, H. Payment for ecosystem services in China: An overview. Living Rev. Landsc. Res. 2011, 5, 2. [CrossRef]

54. Sheng, W.; Zhen, L.; Xie, G.; Xiao, Y. Determining eco-compensation standards based on the ecosystem services value of the mountain ecological forests in Beijing, China. Ecosyst. Serv. 2017, 26, 422-430. [CrossRef]

55. Hansen, K.; Duke, E.; Bond, C.; Purcell, M.; Paige, G. Rancher Preferences for a Payment for Ecosystem Services Program in Southwestern Wyoming. Ecol. Econ. 2018, 146, 240-249. [CrossRef]

56. Zheng, H.; Robinson, B.E.; Liang, Y.C.; Polasky, S.; Ma, D.C.; Wang, F.C.; Ruckelshaus, M.; Ouyang, Z.Y.; Daily, G.C. Benefits, costs, and livelihood implications of a regional payment for ecosystem service program. Proc. Natl. Acad. Sci. USA 2013, 110, 16681-16686. [CrossRef] [PubMed]

57. Wang, S.; Wu, B.; Yang, P. Assessing the changes in land use and ecosystem services in an oasis agricultural region of Yanqi Basin, Northwest China. Environ. Monit. Assess. 2014, 186, 8343-8357. [CrossRef] [PubMed] 
58. Lloyd-Smith, P. A Note on the Robustness of Aggregate Ecosystem Service Values. Ecol. Econ. 2017, 146, 778-780. [CrossRef]

59. Johnston, R.J.; Rosenberger, R.S. Methods, trends and controversies in contemporary benefit transfer. J. Econ. Surv. 2010, 24, 479-510. [CrossRef]

60. Foley, J.A.; DeFries, R.; Asner, G.P.; Barford, C.; Bonan, G.; Carpenter, S.R.; Chapin, F.S.; Coe, M.T.; Daily, G.C.; Gibbs, H.K. Global consequences of land use. Science 2005, 309, 570-574. [CrossRef] [PubMed]

61. Wen, Q.; Guo, G. Taking water pollution into study on water resource ecosystem service valuation-Case study in Jiangsu province. In Proceedings of the Annual Conference of Chinese Society for Environmental Sciences, Beijing, China, 1 August 2015; Volume 6. (In Chinese)

62. Liu, W.; Antonelli, M.; Liu, X.; Yang, H. Towards improvement of grey water footprint assessment: With an illustration for global maize cultivation. J. Clean. Prod. 2017, 147, 1-9. [CrossRef]

2018 by the authors. Licensee MDPI, Basel, Switzerland. This article is an open access article distributed under the terms and conditions of the Creative Commons Attribution (CC BY) license (http:/ / creativecommons.org/licenses/by/4.0/). 